\title{
José Revueltas y la filosofía latinoamericana: imágenes cinematográficas del mundo*
}

\author{
Alejandro Sánchez Lopera*
}

Recibido: 2 de junio de 2015

Evaluado: 27 de julio de 2015 Aceptado: 7 de septiembre de 2015

\section{Resumen}

En este artículo sostengo que la obra del escritor mexicano José Revueltas Sánchez (1914-1976) se aleja de las convenciones de la filosofía latinoamericana, al dejar atrás la experiencia del lamento y la nostalgia por la unidad perdida, así como el extravío del ser sepultado por el colonialismo. Argumento, además, que a ello Revueltas opone un pensamiento sin finalidad y un análisis antimoralista de la verdad. Para lograrlo, postulo que Revueltas utiliza un método basado en la construcción de una imagen cinematográfica del pensamiento. Esto permite construir otra imagen de América Latina, y de su filosofía, por fuera de la moral del sufrimiento o la victimización por parte de Europa. Esa imagen es la de Latinoamérica como isla y no como continente.

Palabras clave: José Revueltas, filosofía latinoamericana, normalización filosófica, cine y pensamiento, imágenes de pensamiento.

* Artículo de investigación, derivado de la tesis doctoral titulada José Revueltas y Roberto Bolaño: formas genéricas de la experiencia, en la Universidad de Pittsburgh. Cómo citar este artículo: Sánchez Lopera, A. (2016). José Revueltas y la filosofía latinoamericana: imágenes cinematográficas del mundo. Hallazgos, 13(25), 41-63 (doi: http://dx.doi.org/10.15332/s1794-3841.2016.0025.02).

** PhD. en Literaturas y Lenguas Hispánicas de la Universidad de Pittsburgh (Estados Unidos). Docente del Departamento de Ciencia Política de la Universidad El Bosque (Colombia). Correo electrónico: als219@pitt.edu 


\section{José Revueltas and Latin American philosophy: cinematographic images of the world}

\begin{abstract}
In this article I argue that the work of Mexican writer José Revueltas Sánchez (1914-1976) moves away from the conventions of Latin American philosophy as it leaves behind the experience of regret and nostalgia for the lost unity as well as the loss of being that was buried under colonialism. I also point out that, in order to achieve this, Revueltas opposes a thought without purpose and a non-moralist analysis of truth. To achieve this, I postulate that Revueltas uses a method based on the construction of a filmic image of thought. This allows him to build a different image of Latin America and its philosophy far from the ethos of suffering and victimization created by Europe. This image is one of Latin America as an island not as a continent.
\end{abstract}

Keywords: José Revueltas, Latin American philosophy, philosophical normalization, cinema and thought, images of thought.
Received: June 2, 2015

Evaluated: July 27, 2015

Accepted: September 7, 2015 


\section{José Revueltas e a filosofia latino americana: imagens cinematográficas do mundo}

Recebido: 2 de junho de 2015

Avaliado: 27 de julho de 2015 Aceito: 7 de setembro de 2015

\section{Resumo}

Neste artigo abordaremos a obra do escritor mexicano José Revueltas Sáchez (1914 - 1976), a qual se distancia das convenções da filosofia latino americana, ao deixar para trás a experiência do lamento e da saudade de uma oportunidade perdida, assim como o extravio do ser, sepultado pelo colonialismo. A isso, Revueltas opõe o pensamento sem finalidade e a análise antimoralista da verdade. Para conseguir esse efeito, Revueltas utiliza um método baseado na construção de uma imagem cinematográfica do pensamento. Isto permite construir outra imagem da América Latina, e de sua filosofia, muito além da moral do sofrimento ou da vitimização por parte da Europa. Essa imagem é a da América Latina como ilha e não como continente.

Palavras-chave: José Revueltas, filosofia latino americana, normalização filosófica, cinema e pensamento, imagens do pensamento. 
Digo isla y pienso en mar.

Digo mar y pienso en isla. ¿Son lo mismo? Se suceden vacío continuo y plenitud sin nombre.

Blanca Varela

José Revueltas Sánchez fue un escritor polémico y prolífico. Fue expulsado del partido Comunista Mexicano dos veces (en 1943 y 1960) y del Consejo Nacional de Huelga de los estudiantes de octubre del 68 en México. Además, fue encarcelado dos veces en Islas Marías. Murió en 1976 en libertad bajo palabra. Al lado de escritores como Octavio Paz, Carlos Fuentes o Juan Rulfo, por décadas la obra literaria de Revueltas fue ubicada en un lugar marginal en el panorama literario mexicano y latinoamericano. Si bien su novela El luto humano (1943) le había merecido el Premio Nacional de Literatura en México, es solo a raíz de su encarcelamiento en Lecumberri en 1968, tras ser acusado de ser el líder intelectual e instigador del movimiento estudiantil del 68 y de la compilación de sus textos escritos hasta el momento en 1967 por la editorial ERA de México, que su obra y práctica política adquieren otra recepción.

En medio del creciente interés que genera su obra, tanto en América Latina como en Estados Unidos, una de las facetas menos exploradas por la crítica es su pasión por el cine. Para el momento en que nació Revueltas (1914), ya el cine contaba con casi dos décadas de existencia; ya era entonces posible un conocimiento cinematográfico del mundo. Paralelo a su militancia comunista y a su escritura de novelas y ensayos filosóficos y políticos, Revueltas trabajó en la adaptación de 35 guiones cinematográficos y dictó cursos de cine en el Instituto Cubano de Arte e Industria Cinematográfica de
Cuba en 1961, y en el Centro Universitario de Estudios Cinematográficos (CUEC) de la Universidad Nacional Autónoma de México (UNAM) (entre 1963 y 1965) (Arévalo, 1983, p. 40). Sin embargo, no es mi intención ocuparme aquí de esos guiones, sino de algo un poco más extraño: la forma como la literatura de Revueltas es tejida a través de un método cinematográfico. En este capítulo sostengo que José Revueltas es capaz de crear a través de su literatura otras imágenes del pensamiento $\mathrm{y}$, por ende, otras imágenes de América Latina. Con la obra de Revueltas es posible cuestionar la idea referente a que el único despliegue posible para el pensamiento en el continente es la filosofía latinoamericana. Salir, entonces, de cualquier hermenéutica del ser latinoamericano. En gran medida, el pensamiento en América Latina se ha reducido a la práctica de la filosofía (especialmente la filosofía universitaria), como lo atestiguan los reiterados intentos de inscribir la filosofía en el ámbito de la "normalización"1.

La obra de Revueltas se aleja de las convenciones de la filosofía latinoamericana al dejar atrás la experiencia del lamento y la nostalgia por la unidad perdida ${ }^{2}$, así como

1 La normalización, según el argentino Francisco Romero en un escrito de 1940, consiste en "el ejercicio de la filosofía como función ordinaria de la cultura, al lado de otras preocupaciones de la existencia. No ya como la meditación o creación de unos pocos entendimientos conscientes de la indiferencia circundante". Y prosigue: "La lectura corriente de escritos filosóficos por interesados cada día más numerosos, el mutuo conocimiento e intercambio entre quienes activamente se ocupan en filosofía, van originando lo que podríamos denominar el 'clima filosófico', una especie de opinión pública especializada que obra y obrará cada vez más, y según los casos, como estímulo y como represión, como impulso y como freno: esto es, como una vaga, indeterminada sanción continua antes y después de los juicios expresos de la crítica, corrigiendo lo que hubiera en estos de partidismo y apreciación individual" (pp. 68-69).

2 Comenta Dussel: "Por una parte, el filósofo latinoamericano debe efectuar la hermenéutica que descubre el sentido de su propia 
el extravío del ser sepultado por el colonialismo. Argumento que a ello Revueltas opone un pensamiento sin finalidad y un análisis antimoralista de la verdad. Para lograrlo, postulo que Revueltas utiliza un método basado en la construcción de una imagen cinematográfica del pensamiento. Esto permite construir otra imagen de América

historia, de su propia realidad, tarea efectuada por Zea, así como Aristóteles exigía que en el uso del método más fundamental de todos, el dialéctico, ni la ciencia ni la filosofía servían, porque debía pensarse directamente taendoxa (las opiniones del 'mundo de la vida cotidiana' desde donde pueden ser pensados los 'principios' de la ciencia y de la misma filosofía en sentido estricto o restringido), y para ello sólo valía la paideia (como una 'cultura', fundamental)" (2005, p. 76). Es Roberto Salazar Ramos quien con más fuerza inicia durante la década de los ochenta la desestabilización del esencialismo e identitarismo de la filosofía latinoamericana. Esta crítica será prolongada por Santiago Castro-Gómez como "crítica de la razón latinoamericana" a mediados de la década de los noventa, extrayendo la formulación del filósofo Daniel Herrera. La crítica es frente a las tesis del ocultamiento o encubrimiento del ser latinoamericano, herederas del traspaso de la filosofía de José Ortega y Gasset en términos de historia de las ideas latinoamericanas. Tal como anota Santiago Castro-Gómez, "el proyecto inicial de la filosofía latinoamericana, tal como fue formulado en México por José Gaos y Leopoldo Zea en la década de los cuarenta, pretendía retomar el historicismo de Ortega y Gasset en clave de historia de las ideas" (2011, pp. 24546). Esta recepción, a través del trabajo de José Gaos, alcanzará un punto máximo en los trabajos del mexicano Leopoldo Zea. El desplazamiento fundamental en esa desestabilización consistió en un principio en recurrir a Xavier Zubiri en vez de a Ortega y Gasset. La lectura de Zubiri se impulsó desde el "Grupo de Bogotá", articulado alrededor de la Universidad Santo Tomás, y conformado básicamente por filósofos y teólogos, el grupo se articuló en torno a los diferentes intereses de sus miembros (la hermenéutica de Paul Ricoeur, la lectura de Marx, la metafísica de Xavier Zubiri). Siguiendo la idea de Zubiri referente a que "toda realidad tiene eso que llamamos su ser. El ser no es la realidad, sino algo fundado en ella, por tanto algo ulterior a su realidad", se abogó entonces por una "meta-física intramundana". Articulados en torno a los Congresos Latinoamericanos de Filosofía realizados en Bogotá periódicamente, entre sus miembros estaban Germán Marquínez, Jaime Rubio, Teresa Houghton, Eudoro Rodríguez Albarracín, Luis José González y Roberto Salazar Ramos. Se pueden consultar los diversos trabajos del Grupo de Bogotá en torno a la filosofía durante la época colonial, la filosofía de la liberación y la religiosidad popular, publicados por la Universidad Santo Tomás y la editorial El Búho, así como los artículos publicados en la revista Cuadernos de Filosofía Latinoamericana, que recogieron reflexiones de diversos países del continente en torno a la situación filosófica, política y cultural de América Latina. Al respecto se puede ver a Sánchez Lopera (2009).
Latina, y de su filosofía, por fuera de la moral del sufrimiento o la victimización por parte de Europa. Esa imagen es la de Latinoamérica como isla y no como continente que, precisamente, contiene las fuerzas y potencias, y las encadena a la idea de una identidad latinoamericana y sus avatares.

De esta manera, Revueltas proporciona una posible respuesta a un acertijo latente en la filosofía latinoamericana del siglo xx: la expulsión o desubicación de América Latina del curso de la historia universal. Hegel es aquí, con sus Lecciones sobre la Filosofía de la Historia Universal, el condenado, al ubicar a América no en la sección de historia, sino en la sección de geografía. Al haber situado a América en la geografía y no en la historia, Hegel despertó un reclamo incesante por parte de la filosofía latinoamericana mayoritaria, de Leopoldo Zea a Enrique Dussel ${ }^{3}$. Frente a esta expulsión del continente latinoamericano, con la literatura de Revueltas es posible dejar de concebir a América Latina como un continente, encubierto o por descubrir. Sin recurrir al reclamo que buena parte de la filosofía latinoamericana le ha hecho a Hegel, Revueltas ofrece una posibilidad para pensar a América Latina ya no como espacio, o continente, sino como

3 Afirma Lepoldo Zea: "hablaremos en este trabajo tratando de continuar el relato de la historia del espíritu que, en Hegel, había llegado a la extraordinaria etapa que representó la Revolución Francesa de 1789 y su antecedente americano, la revolución de 1776. En esta revolución, Hegel pudo ver la explicitación de un futuro del que no quiso hablar, negándose a hacer profecías. Intentamos una filosofía de la historia de nuestra América, como expresión concreta de la historia de la humanidad pugnando realizar ampliamente la idea de libertad, por llegar a ser su máxima encarnación" (1969, 21). Por su parte, escribe Enrique Dussel en sus conferencias en Frankfurt de 1992, su texto conmemoratorio de los 500 años de la conquista de América: "Los pueblos y etnias indígenas americanas no entran en la historia mundial como contexto del descubrimiento de América [...] Debe encontrarse racional e históricamente su lugar en la historia" (1994, p. 86). 
imagen-tiempo: una isla desprendida del continente en perpetuo devenir. Es decir, ya no se trata de seguir a la filosofía latinoamericana que ha concebido a América Latina en términos territoriales: una tierra donde se despliegan identidades y se ejercen las soberanías del yo y del Estado. Una tierra donde se pueden seguir los rastros y señas que nos conduzcan a un origen que diferencie al continente latinoamericano del continente europeo ${ }^{4}$. La idea territorial implica una idea de fijación y una de aridez y sequía. La isla rodeada de agua, por el contrario, implica no solo desplazamiento, sino también un medio húmedo - nada lejos del vendaval que vimos en el capítulo anterior sobre El luto humano-. Isla cuyo centro está en todas partes, que no contiene su propio centro único y territorializable, su punto fijo de identidad, escribe Revueltas en El reojo del yo: "Bien, estamos en esta pequeña isla que tiene su centro en todos los puntos y su circunferencia en ninguno, de acuerdo con la antigua y sabia definición de viejos pensadores ya no discernibles en la Historia" (2014, p. 435).

\section{LA Filosofía LATINOAMERICANA}

La novedad de la forma de pensar de José Revueltas ha sido destacada ya en varias ocasiones. Henri Lefebvre comparó los

4 Durante la Segunda Sesión Plenaria del IX Congreso Interamericano de Filosofía realizado en Caracas en 1977, el argentino Angel Capelleti pronunció una frase en apariencia lapidaria:

"No tiene una filosofía propia el que quiere sino el que puede", la cual dejaba sin sentido, desde el presupuesto de la impotencia, la discusión sobre la posibilidad de "una filosofía enteramente original, una verdadera filosofía de América Latina" (1997, p. 24). Para un análisis de los prejuicios y pasiones presentes en esta afirmación y sus implicaciones para la filosofía latinoamericana, puede verse a Sánchez Lopera (2012). escritos filosóficos de Revueltas con los de la Escuela de Frankfurt, y específicamente con los de T. Adorno, en el prólogo que escribió al texto póstumo de Revueltas, Dialéctica de la Conciencia (1986, p. 14). Revueltas repitió una y otra vez la necesidad de pensar el "todo real de la historia" o "totalidad histórica concreta", evitando entender los hechos o "autonomías fácticas objetivas" como "la propia totalidad independiente y soberana, no devenida sino determinada por sus propias causas internas, autosuficientes y sin historia fuera de su propia historia íntima, circular y petrificada" (1986, pp. 170-71). $\mathrm{Ni}$ el hecho como totalidad autosuficiente, ni totalidad como totalidad hermética y cerrada, y aquí Revueltas sigue a Karel Kosik (quien había asistido al xıII Congreso Internacional de Filosofía celebrado en México en 1963), pues no se pretende ingenuamente conocer todos los aspectos de la realidad sin excepción y ofrecer un cuadro total de la realidad con sus infinitos aspectos y propiedades. La totalidad concreta es una teoría de la realidad y de su conocimiento como realidad, escribe Revueltas (215). La totalidad, entendida en términos dialécticos (de alteración y alteridad), será precisamente el punto de enganche con Frankfurt, que percibe Lefebvre.

Recientemente y lejos de la perspectiva de Frankfurt, Bruno Bosteels comparó su novela Los errores de 1964 con lo que vino a realizar treinta años después el filósofo francés Alain Badiou en sus conferencias tituladas El Siglo ${ }^{5}$. Estas conexiones globales no pare-

5 "What I do know is that Los errores already asks, forty years earlier, some of the same questions that drive Badiou's project in The Century. In particular, Revueltas's novel gives us important insights into the potential destiny of a whole jargon of finitude when it is combined with an antitotalitarian, antidogmatic, left-wing revisionism" (Bosteels, 2012, p. 64). 
cen haber tenido eco en el interior de América Latina. A pesar de una copiosa producción filosófica y política, el diálogo entre el pensamiento de José Revueltas y la filosofía latinoamericana es prácticamente nulo. Quizás la única alusión directa es el liminar que escribe Leopoldo Zea a la novela Los días terrenales de Revueltas (1949). En ese texto, titulado "Revueltas, el endemoniado", Zea comenta acerca de sus relaciones con Revueltas: "nuestro encuentro fue difícil", dice Zea, que considera a José Revueltas un loco. Luego de citar el fustigamiento de Pablo Neruda en contra de Revueltas ${ }^{6}$, habla de la aparición de este en la experiencia de su propio grupo filosófico, Hiperión:

En 1951 se pusieron en marcha varias conferencias sobre el ser y la cultura del mexicano, en las que se formó el grupo filosófico Hiperión. Revueltas fue invitado a dar una conferencia, lo que aceptó con mucho entusiasmo. Tartamudeó algunas palabras y, poniendo la cabeza sobre la mesa de conferencia, empezó a dormir profundamente. (Zea, 1991, p. XVIII).

De manera sintomática, describe la discusión pública que sostuvo con Revueltas en torno a la interpretación de la historia de Hegel:

Respetuosamente me preguntó que de qué estaba hablando; le respondí que sobre la interpretación de la historia de Hegel. Le interesó mucho y me pidió

6 "De hoy en adelante - escribe Neruda - el apellido Revueltas no es uno. Silvestre, el músico, es el Revueltas del pueblo, que el pueblo recordará como uno de los defensores y amigos. Pepe, el escritor, es el Revueltas de la parte más corrompida de la sociedad. La odia, pero en el fondo intenta desarmarla contra ella, pero en el fondo es su avergonzado apóstol" (Citado en Zea, 1991, p. XVII). que continuase, para luego participar en las preguntas hechas por los estudiantes dando su propio enfoque a la historia y pidiendo a los estudiantes liberarse para poder liberar a su pueblo. (Zea, 1991, p. XVIII)

¿Cuál era ese enfoque propio que Revueltas le daba a la historia? Antes de responder esa pregunta, vale anotar que en tanto Zea dedicó numerosos trabajos a comentar esa interpretación de la historia de Hegel, en uno de sus diálogos-respuesta al grupo Hiperión, “Posibilidades y limitaciones del mexicano" (1950), Revueltas se burla de los pensadores que pretenden hallar la especificidad del ser del mexicano. Hegel, vale recordarlo, en sus Lecciones sobre la Filosofía de la Historia Universal había situado a América (la del norte y la del sur) por fuera de la secuencia temporal del espíritu, ubicándola en cambio en el capítulo titulado "La conexión de la naturaleza o los fundamentos geográficos de la historia universal" (1950, p. 171). La indignación que provocó esa exclusión generó una serie de respuestas reiteradas en la tendencia mayoritaria de la filosofía latinoamericana, basada en el esfuerzo de institucionalización y profesionalización de la filosofía denominado normalización filosófica ${ }^{7}$, y en el anhelo de que, por fin, naciera un Hegel latinoamericano ${ }^{8}$.

7 Al respecto, escribe Enrique Dussel: "Estas cortas páginas, una vez más, están dictadas por un espíritu de respeto al gran maestro del pensar latinoamericano, y de agradecimiento por aquella primera lectura de sus obras, cuando en París, al comienzo de la década de los sesenta, me descubrí «fuera de la historia», gracias a Leopoldo Zea" (2005, p. 78). Y añade: "Debo decir que en París, en 1962, comencé a reconstruir el "lugar» de América Latina en la historia mundial, para refutar a Hegel-desde una sugerencia de Leopoldo Zea, el filósofo mexicano" (2005, p. 340).

8 En la sección "Nuestro pasado filosófico" del ensayo titulado "Los orígenes", al referirse a la manera como "el mundo hispánico -España y sus colonias- ha sido suelo estéril para la filosofía", se preguntaba 
Tanto esa interpretación hegeliana de la historia, como la búsqueda del ser mexicano y latinoamericano serán dos tendencias prevalecientes en la filosofía latinoamericana del siglo xx. Es el filósofo argentino radicado en México, Enrique Dussel, quien de manera sintética confronta dicha exclusión en su proyecto intelectual:

Debo reconocer que en esos años, la obra de Zea América como conciencia (1953) me impactó de tal manera que desde aquel momento hasta hoy todo mi intento es justamente posibilitar la 'entrada' de América Latina en la historia mundial (en cuanto a la autointerpretación histórica de la Humanidad, y en cuanto a la 'comunidad hegemónica filosófica). (2005, p. 75)

Además, puntualiza lo siguiente: “Desde hace cuarenta años me hice cargo en primer lugar de la pregunta: ¿Qué lugar ocupa América Latina en la historia universal?, porque estábamos fuera de las interpretaciones estándar de la historia. (1995, pp. 75 y 195). Por un lado, entonces, se buscaba la profundidad de ser, su esencia $u$ origen previo a la expropiación de la conquista europea9. Se buscaba así una correspondencia

el filósofo colombiano Danilo Cruz Vélez: "Aunque en el fondo no quisiéramos formularla, aquí nos sale al paso inevitablemente una pregunta indeseable, a saber: ¿podría generalizarse este aserto y decirse que el hombre hispano carece por esencia de genio filosófico?" (1991, p. 85). El filósofo argentino José Pablo Feinmann afirma en un reciente libro, que "nosotros no tuvimos un Descartes, no tuvimos un sujeto fuerte, no tuvimos un cógito" (2008, p. 30).

9 O'Gorman, en su "destrucción de la metafísica de lo latinoamericano", comenta acerca de la visión de América como "cosa en sí", lo siguiente: "proviene de un previo supuesto en su modo de pensar que, como apriorismo fundamental, condiciona todos sus razonamientos y que ha sido, desde los griegos por lo menos, una de las bases del pensamiento filosófico de Occidente. Aludimos, ya se habrá adivinado, a la viejisima y venerable idea de que las cosas son, ellas, algo en sí mismas, algo per se" (1991, p. 48). Al respecto entre el ser (latinoamericano) y su verdad, entre el sujeto y el mundo. Por el otro, se interpelaba y exigía el derecho a hacer parte de la historia del mundo.

La forma de acercarse a la historia de Revueltas es distinta. A pesar de su tratamiento prejuicioso sobre América, en la lectura Hegel mismo deja escapar una posibilidad, un lapsus. Dice Hegel unas páginas más adelante: "América es el país del porvenir" (1953, p. 180), en un gesto que de alguna manera retorna a América al curso de esa historia. Es en ese gesto que a mi modo de ver se inscribe la concepción de la historia en Revueltas: una historia de América Latina pensada filosóficamente, a través de los recursos que provee la técnica cinematográfica. Pero es una historia que es una historia mundial. Es decir, el problema con Revueltas ya no es Hegel y su presunto prejuicio; es la correlación de fuerzas a nivel mundial, como lo escribió Revueltas una y otra vez en sus ensayos y notas. Más aún, Revueltas se ubicará, como veremos más adelante, por fuera de la perspectiva de denuncia con respecto a Hegel, en su relato titulado "Hegel y yo". Dicha técnica cinematográfica entonces, por un lado, ya no indagará por profundidades, sino por superficies (planos). La composición y el montaje permiten estallar la idea de una historia lineal, tejiendo superposiciones, combinaciones y discontinuidades (como lo hace la mente). Dice Revueltas, tras afirmar que "el montaje es un principio válido, no solo para la obra cinematográfica sino para cualquier obra de arte", que

anota Castro-Gómez: "La pregunta por la filosofía latinoamericana presupone justo aquello que debería ser el resultado de una investigación filosófica. Lo que es resultado de un proceso histórico de producción, a saber, 'Latinoamérica', se toma como si fuese algo constituido de antemano" (2011, p. 247). 
[...] el montaje procede con el mismo método que el intelecto humano al formar, a) las percepciones, sobre la base de una primera impresión o dato sensible; b) las imágenes, sobre la base de un conjunto determinado de percepciones y c) la imagen total del tema, el concepto acabado del mismo, sobre la base de un conjunto combinado de imágenes. (1965, p. 80)

Por otro lado, al evitar pensar América Latina como continente excluido - de la historia y del reino del pensamiento-, con Revueltas es posible cambiar las coordenadas del problema de la herida colonial. Henri Lefebvre, en su prólogo a Dialéctica de la Conciencia, el texto póstumo de Revueltas, fue el primero en señalar esa relación distinta con Hegel: “Así, Revueltas parte de formulaciones muy cercanas a las de Hegel; luego supera el hegelianismo al tomar en cuenta experiencias modernas, atravesando el pensamiento inspirado por Hegel (entre otros, el de Sartre)" (p. 14).

\section{El método de Revueltas}

José Revueltas fue encarcelado dos veces en las Islas Marías. La primera vez, tras participar en la planificación de una huelga en la fábrica El Buen Tono en Ciudad de México con la Juventud Comunista Mexicana (JCM), a la edad de 17 años (Crespi, 1979, p. 95). Las Islas Marías fue una colonia penal a la que por segunda vez en 1933, a los 29, Revueltas fue enviado por dirigir una huelga en Ciudad Anahuac en Nuevo León (Crespi, 1979, p. 95). El encierro será uno de los signos que atravesará su vida. La vida de Revueltas es un navío que regresa de la prisión de las Islas Marías, para embarcarse en el extravío de la imaginación, en medio de tantas ciencias sociales desarrollistas, tanto complejo colonial y tanta literatura nacional. En su travesía revolucionaria, Revueltas imagina un método.

Ejemplo: un escritor compone una novela sobre la vida de un pintor, digamos. Su crítica, es decir su modo de componer, ordenar artísticamente la realidad de aquella vida ha sido tan exacta que en un cierto número de sus lectores logra que éstos descubran su escondida vocación y decidan convertirse en pintores. Este último hecho es la autocrítica. El acto crítico de modificar, componer una realidad en el arte, dio por resultado que esa realidad se modificara en la vida. (1978, p. 95)

La crítica como composición fue lo que ejerció Revueltas. Un modo de componer que radicaliza lo hecho y sugerido por José Carlos Mariátegui, maestro de Revueltas según su testimonio ${ }^{10}$. Mariátegui lo decía con extraordinaria lucidez en La escena contemporánea en 1925, al referirse al estado del mundo:

Pienso que no es posible aprehender en una teoría el entero panorama del mundo contemporáneo. Que no es posible, sobre todo, fijar en una teoría su movimiento. Tenemos que explorarlo y conocerlo, episodio por episodio,

10 "Mariátegui siempre ha sido mi maestro, pero en la cuestión ideológica", comenta Revueltas en una entrevista con Norma Quiteño titulada "Oponer al ahora y aquí de la vida, el ahora y aquí de la muerte": "Fue él quien abrió los ojos a mi generación ante la necesidad de adaptar el marxismo a las condiciones nacionales y continentales y no hacer un marxismo de importación, zafio y de repetición de fórmulas, sino de tratar de captar la realidad nacional" (37). Para un análisis detallado de las relaciones entre Revueltas y Mariátegui ver el texto de Jorge Fuentes Morúa. 
faceta por faceta. Nuestro juicio y nuestra imaginación se sentirán siempre en retardo respecto de la totalidad del fenómeno. Por consiguiente, el mejor método, para explicar y traducir nuestro tiempo es, tal vez, un método un poco periodístico y un poco cinematográfico. (1959, p. 11)

La imagen de este método de composición es delgada como un cabello. Esta imagen trastoca la representación del mundo, entiende el mundo como desajuste, desde el desajuste, lo que implica asumir en plenitud la posible sacudida que alberga un cabello en su materialidad. Jacobo Ponce, personaje de Los errores (1964), novela en la cual Revueltas realiza una evaluación del siglo XX, lee estas líneas:

El hombre es un ser erróneo -comenzó a leer con la mirada, en silencio-; un ser que nunca terminará por establecerse en ninguna parte: aquí radica precisamente su condición revolucionaria y trágica, inapacible. No aspira a realizarse en otro punto -y es decir, en esto encuentra ya su realización suprema-, en otro punto -se repitió- que pueda tener una magnitud mayor al grueso de un cabello, o sea, ese espacio que para la eterna eternidad, y sin que exista poder alguno capaz de remediarlo, dejará siempre sin cubrir la coincidencia máxima del concepto con lo concebido, de la idea con su objeto. (2001, p. 67)

Revueltas sostuvo que el humano es un ser erróneo. Erróneo, no defectuoso o deficitario, como postuló de manera recurrente la cuestión el pensamiento latinoamericano mayoritario al concebir la filosofía latinoamericana. Esto es, como un ser en déficit con respecto a la institucionalización de la filosofía como disciplina normalizada. Los errores es precisamente un intento de evaluar el siglo xx en interioridad, esto es, captar los errores del siglo desde los errores mismos y no desde el acierto o lo correcto. El mundo entonces no es la idea, el objeto no es como lo pienso: no hay pues coincidencia de la idea con su objeto. Mi verdad no es la verdad. El ser erróneo (no defectuoso) habita en un mundo que se construye punto por punto. Cada punto entonces es inconmensurable, y un punto es todo: el espesor de una hebra de cabello se revela entonces como infinito; ningún poder es capaz de mesurar esa vastedad; ningún poder es capaz de esa verdad.

Sin embargo, el punto que ocupa en el espacio y en el tiempo, en el cosmos, la delgadez de un cabello, es un abismo sin medida, más profundo, más extenso, más tangible, menos reducido, aunque quizás más solitario, que la galaxia a que pertenece el planeta donde habita esta extraña y alucinante conciencia que somos los seres humanos. (p. 67)

Cada punto del mundo expresa entonces el mundo mismo. Esa es una bella definición tentativa de lo que muchos llaman universal: lo universal no es el todo respecto a una parte. La cuestión es que cada parte contiene en sí misma el universo entero. Es decir, el universo no es lo que me trasciende y está allá fuera. Es lo que se esconde en mí, en cada cosa, por pequeña que sea, es lo que alberga un cabello en su extraordinaria delgadez: "hay mundos en los mínimos cuerpos" dice Deleuze. Así, el universo no difiere de la cosa en que se expresa: el pez 
son las líneas del mar que son él, la gota es la lluvia; la gota es el mar y toda el agua. En ese sentido, el punto ya no es vincularse a la historia universal como ha postulado la filosofía latinoamericana mayoritaria.

\section{CONCIENCIA, VERDAD, IDEA}

En el duelo sostenido con las grandes filosofías europeas, los filósofos latinoamericanos esgrimieron dos tópicos intentando hallar los rasgos distintivos del continente latinoamericano. Primero, una verdad esencial, primigenia y "oculta" por la dominación europea (la colonización primero y posteriormente el imperialismo). Segundo, la búsqueda continua de un cógito cartesiano en América Latina, pues "nosotros no tuvimos un Descartes, no tuvimos un sujeto fuerte, no tuvimos un cógito" como afirmó recientemente José Pablo Feinmann (2008, p. 30). La forma predilecta para abordar estos tópicos fue la denominada historia de las ideas, corriente intelectual que en América Latina tuvo su impulso decisivo a través de filósofos españoles como José Gaos —quien tradujo al español las lecciones de Hegel a las que aludimos-, el mismo Leopoldo Zea, el colombiano Danilo Cruz Vélez y el argentino Francisco Romero ${ }^{11}$. Figuras dispares de distintas latitudes que, sin embargo, asumieron la tarea de la "normalización de la filosofía" en América Latina y reconocieron en José Ortega y Gasset al filósofo que más lejos había llegado en intentar hacer una filosofía en español, de altura universal. Para

11 Afirma el filósofo colombiano Danilo Cruz Vélez: "En América la Filosofía no es todavía una realidad. Al menos si nos atenemos a lo conocido, es imposible encontrar entre nosotros algo semejante a El Sofista de Platón o a la Metafísica de Aristóteles... 0 a las investigaciones Lógicas de Husserl... para ofrecer solo algunos elocuentes ejemplos" (1985, p. 142). la historia de las ideas, entonces, la conciencia y la verdad representaban los marcos de entendimiento del proceso de pensamiento latinoamericano, expresado a través de linajes de ideas que se remontaban a la época colonial. Además, estaba encapsulada en una extraña obsesión: el advenimiento, por fin, de un Hegel latinoamericano ${ }^{12}$.

Revueltas, por su parte, tomará un rumbo distinto. Más cercano al tipo de reflexión de filósofos como Adolfo Sánchez Vásquez $\mathrm{y}$, más recientemente, Bolívar Echeverría, abordará los mismos tópicos de la filosofía latinoamericana convencional desde otras coordenadas. Construirá un método a partir del cine y el periodismo en la estela de Mariátegui, igual a lo que Revueltas quería de su realismo: "el realismo de un buen reportero, digamos, aquí si exigencia necesaria del oficio, y yo he sido reportero durante largos años" (Revueltas, 2001, p. 20). Método derivado de su concepción del cine, plasmado en su escritura de novelas, adaptaciones de guiones cinematográficos y cuentos: "la síntesis que el arte [cinematográfico] conjunta jamás puede concebirse como un puro proceso de comprensión o como una suma aritmética de cantidades homogéneas" (Revueltas, 1965, p. 9).

Revueltas entiende el cine como pensamiento: plano sobre plano, fondo sobre fondo en una composición voluble, la mente es "naturaleza que se piensa" (1978, p. 163), pero de todos modos naturaleza ciega, al

12 Al respecto comenta Danilo Cruz Vélez: "pero la otra influencia fue una influencia necesaria y decisiva en la normalización de la filosofía en España y América. Para mí es tan importante poner a unos pueblos que nunca habían tenido filosofía a filosofar, poner una lengua como la española que nunca había luchado con los problemas filosóficos a filosofar, es tan importante, repito, como escribir las Investigaciones Lógicas" (Sierra Mejía 36). 
igual que el mundo. Así, sostiene en un ensayo sobre su novela Los días terrenales de 1949 que "el pensamiento no tiene finalidad alguna, del mismo modo que el mundo exterior, en sí mismo, no tiene finalidad alguna" (1978, p. 43). Lo que habría que retratar son las operaciones y no las esencias, pues el origen o el ser son solo una falsa ilusión, un abismo de horror. Bloquear entonces el proceso de comprensión, declararlo caduco.

¿Y la verdad? Aquí nos abrimos a una vida que se pregunta no por cuánto vale la vida o a qué equivale, sino por cómo operan los valores que la informan; vida que se autogobierna, que se da sus propias reglas. Gregorio, personaje de Los días terrenales (1949), describe su forma de conducirse en la vida atada a un destino, pero "el destino no significa — se dijo — sino la consumación de la propia vida de acuerdo con algo a lo que uno desea llegar, aunque las formas de esa consumación resulten inesperadas y sorprendentes no sólo para los otros, sino para uno mismo en primer término" (1991, p. 169). Ese destino debe ser hallado, debe experimentarse desde lo imprevisto: "esa ambición no tienen la misma esencia en todos. En cierta forma es un asunto privado, personal, de temperamento, y cada quien debe encontrarlo. Porque el problema consiste en soportar, resistir la verdad interna de uno mismo, aunque esa verdad sea mentira" ( $p$. 169). Verdad sin verdad, que cada quien puede encontrar, pero es un camino que no se mide por el éxito o el fracaso. Hallar ese destino implica que se pasa, para Olegario Chávez en Los errores, de la verdad del poder, al poder de la verdad:

Entretanto la verdad histórica, al margen del poder, se halla desvalidada, sin amparo, y no posee otro recurso que no sea el poder de la verdad, en oposición a todo lo que representa como fuerza compulsiva, instrumentos represivos, medios de propaganda y demás, la verdad del poder. (Revueltas, 2001, p. 23-24)

Tenemos entonces un ser erróneo (no deficitario), pero aquí el error es distinto al dogma. Contrario al lugar común que en retrospectiva denuncia al Partido como la verdad y a la historia como expresión teleológica de la dialéctica, Revueltas retorna la dialéctica a la conciencia del humano, no a una pretendida lógica inexorable de la historia. La conciencia humana entonces está en una relación dialéctica con la realidad y es ese carácter dialéctico el que impide una reconciliación final (salvífica) del humano con el mundo en la versión común del Partido. Y devuelve la cuestión de la verdad, no al sujeto, sino a la perspectiva. La verdad entonces no es una unidad o una revelación, es una posible perspectiva entre otras: igual que en el cine con sus múltiples planos, tomas y cortes en la acción, la verdad es una posible perspectiva sobre el mundo, no la perspectiva sobre el mundo. El montaje en el cine "evita" confundirá la imagen proyectada con la realidad: la imagen no es el mundo, así como mi verdad no es la verdad. "La imagen del mundo se desmigaja en el cine moderno, pues ya no hay fundamento en el que colocar cualquier presupuesto de verdad" (Barragán, 2012, p. 173). La verdad no está entonces ligada al ser, sino que es un conjunto creciente de perspectivas: "La única verdad es la falta de verdad: verdades concretas, transitorias, tangibles" dice Jacobo Ponce en la novela Los errores (Revueltas, 2001, p. 71). Pero la perspectiva no necesariamente es un candoroso pluralismo, 
no es que sea algo bueno: la perspectiva es imposición, avidez, dominación. Por eso el problema no es si las verdades son ciertas o falsas, sino su grado de concreción, de materialidad. Su fuerza. La pregunta entonces sería no si la verdad es cierta, sino cuáles son los elementos que la hacen surgir y desaparecer, cómo una verdad llega al mundo, cómo se hace material. ¿Y la conciencia? Está desligada de las ilusiones que el individuo fabrica para sí: "La mente es algo curioso y casi inverosímil", comenta Revueltas: "Tiene una extraordinaria semejanza con un escenario de esos muy profundos - tanto que se sentiría vértigo- que tuviese una serie sucesiva de decoraciones imprevistas. Primero una, después otra y otra, sin acabar jamás, porque la mente, en el fondo, es insondable" (2001, p. 64). La mente es insondable porque está desfondada, abismal porque, al igual que la mónada, no es un haz de claridad, sino un fondo sombrío. También, prosigue Revueltas en contra de cualquier hermenéutica o previsión sacerdotal,

se parece a dos grandes y descomunales espejos encontrados, que se reprodujeran a sí mismos sin cansancio y de una manera tan infinita como en las pesadillas, con la diferencia que a medida en que apareciesen nuevos espejos - espejos y espejos como una torre de Babel- las figuras reproducidas fueran siendo otras o, con mayor exactitud, las mismas, pero vistas en aspectos desconocidos, como si a cada nueva aparición se descompusieran en sus elementos integrantes creando la falsa idea de que, después de algún tiempo, en el más lejano y último de los espejos, acabaría por encontrárselas, simples ya, y como quien dice "monocelulares", poniendo al descubierto su origen $\mathrm{y}$ con ello el origen de todas las cosas, el secreto del universo y el principio de todo lo que existe. (p. 64)

Abrirse a las decoraciones imprevistas antes que congelarse en la imagen final, que sería la primera, el reflejo primigenio del yo. Imagen final siempre alentada por las preguntas de la filosofía latinoamericana: ¿quién soy?, ¿de dónde vengo?, ¿cuál es la verdad de mi ser? Por supuesto, ese espejo al final de la fatigada búsqueda no deja de ser un autoengaño. Ni siquiera la más persistente de las ilusiones, la del yo pensante, es capaz de reflejarse allí:

Pero ya se ha dicho que, en todo caso -y aun dejándose llevar por ilusiones ópticas-, se trata de una falsa idea o si se quiere, de un "espejismo". La mente, no obstante, es así. Nosotros somos un pensamiento, una emoción, un instinto. Mas todos ellos - y cada uno en lo particular - se pueden descomponer en mil pedazos y no encontraremos jamás el camino, no encontraremos jamás lo simple ni lo primario. (p. 65)

No hay entonces camino a lo primario; no hay ninguna senda al origen de nuestras esencias robadas o expropiadas por Europa y su imperialismo político o filosófico. A partir de eso, antes que un sismógrafo que detecta peligros y fallas, ¿se puede decir que América Latina no carece de nada, no le falta nada? Tal vez, si somos capaces de afirmar una composición distinta: no habría una verdad que secuestraron, o una verdad por venir en el continente. En América Latina somos tan perfectos como podemos ser, potencia plena de fuerzas afirmativas y erráticas. Somos capaces de verdad y de no 
verdad, pero, ¿somos capaces de vivir sin verdad, sin encumbrar subrepticiamente el veneno del ideal, del otro mundo? La respuesta de Revueltas es afirmativa: pero entonces hay que construir un método acorde con esa riqueza. Y dar el paso de la idea, a la imagen: de la trascendencia de las cosas superiores a la gente, a la consistencia del espesor de un cabello; antes que la idea de la mente o el bien, la materia del cabello.

\section{América Latina como imagen}

En tanto la filosofía latinoamericana intentó pensar a América Latina desde la historia de las ideas, el método de José Revueltas produjo un camino distinto. En lugar de recorrer la senda de la filosofía disciplinar, mapeando su normalización y sus maestros como lo hizo la tendencia mayoritaria, la novedad que introduce Revueltas es el intento de pensar filosóficamente desde la literatura. ¿Era posible dejar de usar la literatura latinoamericana, para corroborar las tesis postuladas desde la filosofía? Sostengo que sí, pero para dar ese paso era necesario abrirse a una escritura acorde con la velocidad y riqueza del mundo: no era posible seguir captando el mundo, su velocidad, desórdenes e inconsistencias desde la quietud. Era necesario, como ya lo advertimos con Mariátegui, un método cinematográfico, capaz de pensar a partir de la literatura misma, en pleno movimiento.

Para efectuar el distanciamiento con la filosofía latinoamericana, Revueltas desplazó el foco de atención desde el espacio hacia el tiempo. El punto ya no era concebir a América Latina como continente en el espacio, sino como imagen en el tiempo. Eso le implicó a Revueltas hacer dos revaluaciones fundamentales. Por un lado, abrirse a la posibilidad de una escritura de la historia no lineal, que evitara seguir el linaje que lleva a los orígenes. Por el otro, postular otro tipo de memoria, desligada de cualquier predicado sustancial o esencial: una forma del recuerdo que no revelara o confesara nuestro principio confiscado. Sobre lo primero, escribe Revueltas en el texto "Autogestión académica, y universidad crítica", de 1971:

La acción teórica, el acto histórico, no pueden comprenderse sino en su fluir, unido a una sucesión de momentos que jamás ofrecen una continuidad lineal ni resisten una definición unívoca. Hay una especie de geología de las corrientes históricas, en que estas se subsumen, recorren un trayecto subterráneo y tortuoso, para emerger años más tarde, bajo formas diferentes y actuadas por otros personajes. (2003, p. 152)

Ya no hay aquí una suerte de hermenéutica tratando de auscultar el ser profundo y oculto en América Latina, sino una geología que puede conducir por sendas inesperadas, a través de un análisis de la materialidad del mundo. Para esta geología, la cuestión ya no es hacer un reclamo por haber ubicado a Latinoamérica en el área geográfica. Por el lado del recuerdo (tema sobre el que volveré en el capítulo referido al 68 en México), Revueltas plantea la materialidad de una memoria desligada de la conciencia: evita el invocar una memoria psicológica. Años después de lo escrito por Revueltas, en sus libros sobre cine, Gilles Deleuze dirá que lo que es luminoso es la materia, y que el supuesto centro de comprensión, la conciencia, es un lugar más entre otros: "mi cuerpo es una imagen, y por lo tanto un conjunto de acciones y reacciones. Mi ojo, mi cerebro, 
son imágenes, partes de mi cuerpo. ¿Cómo podría contener mi cerebro las imágenes, si él es una entre las demás?". Y puntualiza: "Decid que mi cuerpo es materia, o decid que es imagen [...]" (1984, pp. 90-91). En el reino de la imagen, sujeto y acontecimiento son inconmensurables, pues están ubicados de forma simultánea en el mismo plano móvil, cada uno valiendo por sí mismo, así como en sus contaminaciones y cruces recíprocos. Al igual que la mente, el sujeto es una imagen entre otras, como se lee en $E l$ luto humano, novela fustigada por Octavio Paz"13: "Existo y me lo comunican mi cuerpo y mi espíritu, que van a dejar de existir; he participado del milagro indecible he pertenecido. Fui parte y factor, y el vivir me otorgó una dignidad inmaculada, semejante a la que puede tener la estrella, la mar o la nebulosa" (Revueltas, 1989, p. 91).

Revueltas es capaz de crear imágenes, pero son imágenes que no representan el mundo: no se corresponden con un objeto, ni tampoco son realidades psicológicas alojadas en la conciencia. Estas imágenes sin semejanza

13 Ver los comentarios de Octavio Paz sobre El Luto Humano en sus dos notas de 1943 y 1979. En la "Primera nota" de 1943, escribe: "Una constante preocupación religiosa invade la obra: Io mexicanos, piadosos por naturaleza, y enamorados de la sangre, han sido despojados de su religión, sin que la católica les haya servido para satisfacer su pétrea sed de identidad" (1985, p 11); "Revueltas siente una especie de asco religioso, de amor hecho de horror y repulsión hacia México" (1985, p. 12). En 1979, en su "Segunda Nota", escribe: "Pero hay algo que distingue a las dudas y a las críticas de Revueltas de las otras: el tono, la pasión religiosa. Y hay más: las preguntas que una y otra vez se hizo Revueltas no tienen sentido ni pueden desplegarse sino dentro de una perspectiva religiosa. No la de cualquier religión, sino precisamente la del cristianismo" (1985, p. 15). El misreading de Paz es inmenso, y permite entender las incomprensiones que ha tenido la recepción de la obra de Revueltas. Baste señalar simplemente que lo que Paz ve como teología es puro materialismo: el carácter inmortal de esa cosa de la cual los personajes de Revueltas son síntomas no proviene de algo teológico: es el materialismo del sujeto. Del mismo modo que el inconsciente es indestructible, lo es el sujeto. más verdaderas que el objeto, pura imagen en los términos de Deleuze (1984, p. 90-91), se expresan en la forma en que Ezequiel, en Ezequiel o la matanza de los inocentes, recuerda lo sucedido en la masacre de Tlatelolco en el 68:

Las cosas, en su derredor, se le daban a Ezequiel desnudas de toda significación, en su naturaleza concreta y pura, bajo una única, desolada e incompartible denominación monolítica a la cual habían llegado mediante un proceso minucioso de autodestilación en que se despojaban, una a una, de todas las mediaciones que las encubrieran a lo largo del tiempo y de la historia, como serpientes que abandonasen una sucesión infinita de epidermis o un fruto que se fuese desprendiendo de las cáscaras a la búsqueda de lo que eran como tales cosas que no se sabían. (Revueltas, 1998, p. 32)

En ese momento es cuando para Ezequiel el recuerdo aparece como recuerdo; no recuerdo de o sobre algo, sino recuerdo en tanto recuerdo. Imagen inmediata y sin raíz que la evoque, imagen sin concepto - "memoria sin lenguaje", como afirma Revueltas en Hegel y yo (1985, p. 134)— relato escrito durante su encarcelamiento en Lecumberri por los sucesos del 68. O en Ezequiel:

Un proceso del recuerdo en el que éste se desdoblaba, siempre hacia atrás, en una encarnizada unilateralidad de repetidas transparencias, hasta convertirse en la acción absoluta de recordar, desprovista ya de la cosa recordada, y ésta quedaba reducida a no ser ninguna otra noción o simple actitud por fuera del recuerdo puro de sí, a salvo de 
cualquier peligro, incitación, impulso o deseo de compartirse con nadie como cosa genérica, universal. (1998, p. 32)

En contra de la representación universal, está la imagen como singularidad pura, pensamiento en sobrevuelo desligado del significante. Así como en Los errores Revueltas evalúa el siglo xx desde la interioridad del siglo $\mathrm{xx}$, en La matanza de los locos capta el recuerdo como inmanencia radical sostenido por una evaluación interna al recuerdo mismo. El cuerpo como imagen, el texto como imagen. Si el método imaginado por Revueltas es la composición, en este punto se adiciona la cualidad que lleva esa composición a desplegar toda su fuerza: composición cinematográfica.

En su lectura de Los días terrenales, titulada Ángeles en el abismo. Las imágenes dialécticas de Walter Benjamin y José Revueltas, para Rogelio Espinoza José Revueltas captura las “imágenes dialécticas, policronías espaciales que conjugan en un solo espacio/tiempo las eras imaginarias del México prehispánico, colonial y moderno" (2007, p. 231). La escena de Los días terrenales a la que alude Espinoza efectivamente va en esa dirección:

México trastoca, subvierte los puntos cardinales, y al mezclar el pan y el vino del tiempo y el espacio se transustancia en una unidad extraña que hace posible la convivencia de sucesos ocurridos hace cuatro siglos con cosas existentes hoy; piedras que ya existían en el año de Ce-Ácatl con campanas y fábricas y estaciones y ferrocarriles. Escuchó con atención de ciego, tenazmente, igual que un avaro, con una especie de sed. Voces que venían desde Tlatelolco, donde Zumárraga edificó el Colegio de los Indios
Nobles, se escuchaban a más de dos o tres kilómetros, en la plaza donde los acróbatas de Moctezuma hacían el juego de El Volador; lamentos y silbatos provenientes de Popotla, de Azcapotzalco. (2007, p. 43)

Todos los tiempos al tiempo en espacios conjugados, en una operación que desbarajusta los puntos cardinales. El punto cardinal está fijado por el movimiento de los astros, del Sol. Son puntos fijos que intentan mapear el mundo a partir del movimiento. Precisamente, el tiempo es la dimensión fundamental de la imagen, y la imagen en movimiento es la que subvierte los puntos cardinales (el espacio). Es la imagen del cine. Las peculiares relaciones entre tiempo e imagen son la gran invención del cine moderno. El plano móvil está lleno de imágenes, y ese plano es antirepresentativo o, más precisamente, es no-representativo: no es un mapa del espacio, es una imagen del tiempo.

Como ya anoté, Henri Lefebvre en el prólogo al texto final de Revueltas, Dialéctica de la conciencia, diagnosticó sintonías entre la obra de Revueltas y la de T. W. Adorno. Señaló cómo "Revueltas muestra 'en acto' las contradicciones; las muestra actuando en la conciencia", fundamentando la dialéctica en el sujeto y no en el objeto. Recientemente, como ya se dijo, Bruno Bosteels ha señalado similitudes de Revueltas con respecto a Walter Benjamin y Alain Badiou. Si escuchamos las palabras de Ejel en el relato Hegel y yo de Revueltas ("la memoria no es lo que se recuerda sino lo que olvidamos, la memoria es lo que uno hace y nadie ha visto, lo que no tiene recuerdo. Añade luego: 'no somos sino pura memoria y nada más'”) (1985, p. 129), a lo que podría incluso 
añadirse el Foucault-Bergson de Deleuze: "Pero el tiempo como sujeto, o más bien subjetivación, se llama memoria. No esa corta memoria que viene después, y que se opone al olvido, sino la 'absoluta memoria' que dobla el presente, que redobla el afuera y que se identifica con el olvido" (p. 141). En fin, el sobrevuelo de un pensamiento libre se intersecta con sus afinidades despegado de la tierra, en un plano de intensidades. Es un animal cósmico que, como bestia que es, revienta la cadena de las causas e influencias. Revueltas, por supuesto, no es un adelantado ni una anticipación. Es simplemente la historia de otro tipo de práctica vital. Una forma de vida disímil.

Así, la mencionada cercanía de Revueltas con distintos filósofos europeos pertenecientes a tradiciones de pensamiento dispares (Benjamin, Adorno, Badiou) se transforma no en un problema de influencias e intertextualidades, o de nivelación pos/ de-colonial (como diciendo, aquí en América Latina también hay pensamiento). No se trata de saber tampoco si Revueltas leyó a Adorno o Benjamin, o si su pensamiento es equiparable - todo lo contrario-, el diferencial del pensamiento busca poner en relación cantidades no comparables, busca navegar sobre el diferencial de potencias. Pero sí que, en momentos y perspectivas distintos, se instalaron en series de problemas similares, en combates morales que resuenan entre sí. El problema es entonces de ubicación. Es decir, la escritura de Revueltas, su método, se ubica en el plano del cine moderno, y este último abre otro camino para el pensamiento, provee una nueva imagen del pensamiento, dice Deleuze. La idea, por su lado, en su soberanía reparte dádivas: la trascendencia es la fuente del bálsamo para aguantar el hecho de estar vivos. La imagen, por su parte, es inmanencia pura, como soporte del mundo.

Pues no es en nombre de un mundo mejor o más verdadero como el pensamiento capta lo intolerable de éste; al contrario, es porque este mundo es intolerable por lo que él ya no puede pensar un mundo ni pensarse a sí mismo. Lo intolerable ya no es una injusticia suprema, sino el estado permanente de una banalidad cotidiana. El hombre 'no es él mismo' un mundo distinto de aquel en el cual experimenta lo intolerable, y donde se experimenta atrapado. (Deleuze, 1987, p. 227)

Esto, por supuesto, explicaría mejor el sentido de muchos de los personajes de Revueltas: se acusa a sus personajes (y a Revueltas mismo) por desdichados o desesperanza$\operatorname{dos}^{14}$. Pero aquí hay otra posibilidad: lo que

14 Pablo Neruda y Octavio Paz, entre tantos otros, se quejaron de Revueltas. Paz escribió que "Revueltas siente una especie de asco religioso, de amor hecho de horror y repulsión, hacia México" (1985, p. 12). Es el crítico norteamericano James Irby, en su tesis de maestría (a la que Revueltas responderá) quien en 1956 instala el tono de lo que será la literatura crítica sobre Revueltas, al escribir: "La filosofía de Revueltas se caracteriza más bien por un materialismo estático y muerto y un fatalismo atroz que anulan acción y movimiento y crean personajes unilaterales, sin desarrollo interno, meras figuras" (citado en Torres, p. 259). Comentando específicamente El luto humano, Edith Negrín se refiere a "la atmósfera de impotencia y desencanto que impregna el relato" (1992, p. 96) y José Ortega arguye que la "falta de progresión, de historia, que permea el relato se pone de relieve desde las primeras páginas. La repetición al principio y al fin del párrafo, así como en el centro, sirve para enfatizar un monótono y fatídico pendular [...]" (1999, p. 103). Para lo que es el último desarrollo de la tesis negativa sobre las "fallas" de Revueltas, especialmente en términos de la disonancia entre sus proyectos políticos y literarios, ver el texto de Ignacio Sánchez Prado (2007). En décadas pasadas ha surgido, sin embargo, una posición afirmativa sobre Revueltas, minoritaria de todos modos, donde el nombre clave es Evodio Escalante. En esa misma dirección, los recientes trabajos de Bruno Bosteels han profundizado esa lectura afirmativa de Revueltas (2005 y 2012). Es en ese estilo de análisis donde inscribo este capítulo. Dirección afirmativa que fue expresada ya por Escalante hace unos años: "A la eficacia 
es intolerable entonces es el mundo, no quien lo observa. Revueltas recuerda que la luz nueva del mundo se renueva sin cesar. La luz, como dijimos, viene del mundo, no del cansancio lúgubre del sujeto que juzga las fuerzas del día. Luz que cambia con el mundo y no envejece en el atrio del tribunal. Luz, entonces, para ver las imágenes y no para guiar las conciencias o domesticarlas. Luminosidad del mundo para concebir Latinoamérica como algo afirmativo e incierto y no como tierra del porvenir o escena del origen perdido. Luz para suspender la obsesión por América Latina como continente, como algo que contiene. Así como la escritura pasa del carácter a la imagen, América Latina puede pasar del mapa al plano (o pantalla). La pregunta con Revueltas ya no es qué son las cosas, qué es el mundo, qué es América Latina, qué es la identidad o el ser, qué son los objetos:

Entonces aquí descubría Ezequiel el hecho insólito y sobrecogedor de que si se interrogara a sí mismo acerca de lo que es la madera, esa abismal y compenetrada madera terrestre, si acertara a preguntarse lo que significa, qué es lo que la decide madera y aquello en que se asume, su olor o su ruido o sus sueños oceánicos o su sordera unánime de pez ciego o el mundo y la nada o la sombre de lo que proyecta la sombra, qué es, qué es, no sabría contestarse y la palabra madera se iría convirtiendo en una mancha loca y aterrada, la sustancia universal de que está hecha la muerte

represiva de una sociedad confinatoria, que pone a su servicio las fuerzas invencibles de una geometría enajenada, José Revueltas opone la naturaleza libertaria de un acto inmemorial, que surge de lo profundo, sin razón aparente. Me gustaría que el nombre de Revueltas se asociara siempre, entre otras cosas, a ese acto inmemorial intrínsecamente afirmativo" (1999, p. 162). de ese espacio que se extiende como un aceite de silencio de un planeta a otro, el infinito de madera. (198, p. 32)

La pregunta, entonces, es otra. Nietzsche nos recuerda siempre el preguntar por quién quiere eso, quién quiere que busquemos el qué de las cosas. El reino de la imagen opera en medio de singularidades que desquician el significante, mancha loca y aterrada. A su vez, define las cosas desde su interior: no opera como aquel que señala las cosas, les da un nombre y así les otorga su función o su ser. Se trataría pues de definir las cosas en interioridad, no desde el mecanismo lingüístico que se posa desde afuera sobre las cosas. Definir entonces en interioridad a América Latina. Abrirnos a otra imagen del pensamiento produciría otra imagen de América Latina y viceversa. La pregunta es: ¿somos entonces capaces de concebir a América Latina como imagen, y no como idea o discurso? Como cuerpo, que es imagen, y no representación. Con Revueltas es posible embarcar a América Latina en un navío arrancado de cualquier raíz o igualdad identitaria. Su técnica de escritura es la composición cinematográfica: así como el cine no representa el mundo, la literatura de Revueltas impide la metáfora de la representación (esto es aquello; esto remite a lo otro). América Latina no está incrustada en el espacio de la representación, ya que ese espacio en Revueltas, como en el cine, se convierte en un plano móvil, un plano sin profundidad que cambia a cada instante.

\section{América Latina como isla}

El espacio de la representación y su juego de ideas es el espacio del continente, tieso y compacto: América Latina como continente 
o espacio seco en busca de una esencia que conjure el ataque imperial, o restaure el daño colonial. El plano móvil, por el contrario, América Latina como imagen, es una isla en su deriva desprendida del continente: "El cine, luego, puede tomarse como esta 'estabilidad de la inestabilidad de que nos habla Heráclito, la estabilidad móvil, el reposo en movimiento" (Revueltas, 1965, p. 11). Es el movimiento estático, del que luego hablará Deleuze.

De alguna manera, la imagen se descongela, y la heterogeneidad del movimiento (la isla) se vuelve irreductible a la homogeneidad del espacio (el continente). El todo cambia su naturaleza en cada movimiento. Así, América Latina sería una isla en movimiento y no un continente en el espacio. Cúmulo de imágenes, no idea. ¿Podemos captar una visión de América Latina como mundo material de "variación universal"?:

Los objetos, los cuerpos, son múltiples, infernalmente variados. Pero eso es allá, en el otro tiempo, en el otro mundo, el de los vivos. Esta circunstancia -su diabólica multiplicidad- influye directamente en la propia, rotunda, e inimaginable naturaleza de los objetos. Son tan plurales, allá, que dejan súbitamente de existir. (Revueltas, 1981, p. 66)

Es la materia entonces la que es iluminada, es el mundo el que es indiferente a nosotros en su variación infernal. La luz, como dijimos, proviene del mundo, no del ojo. Estamos frente a "un mundo que vibra al propio nivel de la materia poblado por imágenes previas al sujeto". Los procedimientos de Revueltas recuerdan que la imagen movimiento es la máquina de hacer ver afectos y sensaciones que el discurso oscurece; el discurso opera ordenando y conteniendo lo múltiple. Máquina para ver la inmensa montaña oscurecida para que por fin nos salgan lágrimas, capaz de pintar no las ideas ni los discursos, sino las fuerzas.

Los grandes escritores -ha dicho Maurois, y habría que extender el concepto a todos los artistas-, emplean palabras no para bosquejar mundos imposibles, sino para evocar y establecer el mundo verdadero. Este mundo verdadero que el arte revela según Maurois, es ese que, sin decirlo, sin pronunciarlo, sin oírlo, se escucha con los puros sentidos del corazón, porque el arte usa las cosas visibles y audibles para mostrar las cosas invisibles e inaudibles. (Revueltas, 1965, pp. 12-13)

Es hacer visible el mundo real, pero visibilizarlo en su riqueza y complejidad. Volver al mundo. Atacar la fábrica del ideal, el taller de mundos ilusorios de espaldas a la experiencia. Habitar no el mundo verdadero, sino el mundo como tal. Planear sobre su superficie, y evitar así la tentación de caer en la navegación de las profundidades. Ese es el pálpito de José Revueltas. Eso sería construir una imagen cinematográfica del pensamiento; hacer que el pensamiento sea imagen. Así, el proyector a partir del cual se generan las imágenes no sería la conciencia, sería el mundo mismo, siempre en vías de hacerse. La crítica vendría a ser la artesanía de componer imágenes, como invitación a "creer, no en otro mundo sino en el vínculo del hombre con el mundo" como sugiere Deleuze. La imagen como pensamiento, el pensamiento como imagen: ese es el sutil arte de volver al mundo. 
A su vez, la estructura interna del montaje, por lo que a ella respecta, consiste en la combinación, yuxtaposición e interpenetración de valores diversos, a efectos de obtener un todo armónico que represente algomás que sus partes, es decir, un todo que sea un resultado cualitativo general diferente al valor cuantitativo particular de los elementos que lo integran. (Revueltas, 1965, pp. 20-21)

Ese algo más no es un líder, una doctrina o un Dios: es simplemente ese exceso que se alberga en la fragilidad de un cabello. Revueltas cita aquí a Rilke: "Una mano que se posa sobre la espalda o el muslo de otro cuerpo no pertenece ya aquel del que proviene: ella $\mathrm{y}$ el objeto que toca o agarra forman juntos una nueva cosa, una cosa más que no tiene nombre y no pertenece a nadie". Entonces señala: “Esa cosa 'que no tiene nombre', es, ni más ni menos, el resultado de un montaje, es decir, el resultado de una combinación, de una yuxtaposición de valores diferentes que, unidos, arrojan un valor nuevo" (21). Ese algo más, algo impersonal, ese valor nuevo que es efecto de una suma que no totaliza, es el todo como imagen, una imagen descongelándose y saliendo de su letargo. Es la isla-imagen abierta a lo común, anónima, NN. Es la valoración renovada: la posibilidad de una invención moral. Es el acontecimiento. Así, antes que un simple pesimismo, una angustia vana ante el fin del uno, Revueltas ofrece un sujeto disociado, pero no solo en su interior, sino con respecto al encierro de la sociedad: Revueltas prisionero, cuanto más encerrado, más abierto al mundo. Fue encerrado dos veces en una isla, las Islas Marías, teniendo en cuenta que la isla en su deriva se desprende del continente.
Pensamiento sin finalidad, verdad antimoralista, imágenes cinematográficas, son entonces los resortes del mundo de José Revueltas. ¿Podremos nosotros habitar ese mundo? Revueltas nos propone una voluntad de mundo, precisamente contra la pérdida del mundo. Una voluntad de isla frente al iceberg continental, aquella costra que, como continente, contiene las fuerzas y las doma, al sancionarlas en vez de valorarlas. Revueltas se embarcó en esa nave hace mucho tiempo, en el ir y venir del apando al espacio abierto, del continente a las Islas Marías, del individuo al mundo: "así que es imperioso [dice Gregorio en Los días terrenales] buscar algo parecido a una forma, digamos, de solidaridad inversa, que nos destruya, que nos anule, que nos liquide, que nos despersonalice como individuos, y esa forma no puede ser sino la responsabilidad común en lo malo y lo bueno" (2007, p. 146). En lo malo y en lo bueno, en el mundo tal cual es, como amor al mundo, amor a todo lo que acontece. El otro pasajero de esa embarcación, Gregorio, sigue entrando en el mundo al entrar de nuevo en la sala de tortura: "Esa era su verdad. Estaba bien" (2007, p. 170). La dirección del navío de Revueltas es este mundo, descongelado y ardiente.

\section{REFERENCIAS}

Arévalo, J. (1983). Revueltas y el cine. La Brújula en el bolsillo, 8,

Barragán, Ó. (2012). Filosofía como política, fabulación y cine. Nietzsche, Bergson, Nancy y Deleuze. Nómadas, 37, 83-171.

Bosteels, B. (2012). Marx and Freud in Latin America: politics, psychoanalysis, and religion in times of terror. Nueva York: Verso Bosteels, B. (2005). Una arqueología del porvenir: acto, memoria, dialéctica. $L a$ 
Palabra y el Hombre: Revista de la Universidad Veracruzana, 134, 161-71.

Capelleti, A. (1977). Historia y evolución de las ideas filosóficas en América Latina. Revista Javeriana, 439, 17-24.

Castro-Gómez, S. (2011). Crítica de la razón Latinoamericana (2da. dición). Bogotá: Pontificia Universidad Javeriana

Crespi, R. (1979). Jose Revueltas (19141976): a political biography. Latin American Perspectives. Studies on the State and Development and on Popular Mobilization, 6.3, 93-113. Print.

Cruz Vélez, D. (1991). La filosofía en Latinoamérica: ¿posibilidad o realidad? En al encuentro de la cultura Hispanoamericana. Bogotá: Banco de la República.

Cruz Vélez, D. (1991). Tabula Rasa. Bogotá: Planeta.

Deleuze, G. (1987). Foucault. Barcelona: Paidós.

Deleuze, G. (1984). La imagen-movimiento. Estudios sobre cine 1. Barcelona: Paidós.

Deleuze, G. (1987). La imagen-tiempo. Estudios sobre cine 2. Barcelona: Paidós.

Dussel, E. (1994). 1492. El encubrimiento del otro. Hacia el origen del "mito de la modernidad". La Paz: Plural Editores, CID UMSA,

Dussel, E. (2005). Modernidad, imperios europeos, colonialismo y capitalismo (para entender el proceso de la transmodernidad). En Materiales para una política de la liberación. México, D.F.: Universidad Autónoma de Nuevo León.

Dussel, E. (2007). Materiales para una politica de la liberación. México, D.F.: Universidad Autónoma de Nuevo León.

Escalante, E. (1999). Preposteración y alienación generalizada en El Apando de José Revueltas. En E. Negrin (Ed.),
Nocturno en que todo se oye. José Revueltas ante la crítica. México, D.F.: ERA.

Espinoza, R. (2007). Ángeles en elaAbismo. Las imágenes dialécticas de Walter Benjamin y José Revueltas. Acta Poetica, 28, 1-2.

Feinmann, J. P. (2008). ¿Qué es la filosofía? Buenos Aires: Prometeo.

Fuentes Morúa, J. (2002). La formación de la problemática nacional en el pensamiento de José Revueltas. Polis: Investigación y Análisis Sociopolítico y Psicosocial, 0.2, 173-93.

Hegel, G.F.W. (1953). Lecciones de filosofía de la historia universal (Vol. I). Madrid: Revista de Occidente.

Lefebvre, H. (1986). Dialéctica de la conciencia. En Obras Completas. México, D.F.: ERA.

Mariátegui, J. C. (1996). La Escena Contemporánea. Lima: Biblioteca Amauta, 1959. Print.

Negrin, E. (1992). El luto humano y la narrativa mexicana que lo precede. Literatura mexicana 3.1, 93-122.

Ortega y Gasset, J. (1999). José Revueltas: dos aproximaciones. En Negrín, E. (Ed.), Nocturno en que todo se oye. José Revueltas ante la crítica (pp. 98-109). México, D.F.: ERA.

O'Gorman, E. (1991). La invención de América (2da. edición). México, D. F.: Fondo de Cultura Económica.

Paz, O. (1985). Cristianismo y revolución: José Revueltas. En A. Revueltas y P. Cheron (Eds.), José Revueltas. El apando y otros relatos. Madrid: Alianza.

Castro Quiteño, N. (2001). Oponer al ahora y aquí de la vida, el ahora y aquí de la muerte. En A. Revueltas y P, Cheron (Eds.), Conversaciones Con José Revueltas. México D.F.: ERA.. 
Revueltas, J. (1965). El conocimiento cinematográfico y sus pr oblemas. México, D. F: Universidad Nacional Aautónoma de México.

Revueltas, J. (2003). Autogestión académica y universidad crítica. En A. Revueltas y P, Cheron (Eds.), José Revueltas. México 68: Juventud Y Revolución. México, D.F.: ERA.

Revueltas, J. (1978). Por una literatura nacional (mesa redonda). En Cuestionamientos e intenciones. México D.F.: ERA.

Revueltas, J. (1978a). Problemas del conocimiento estético. En Cuestionamientos e intenciones México, D.F: ERA.

Revueltas, J. (1978b). Esquema sobre las cuestiones del materialismo dialéctico y la estética a propósito de Los días terrenales. Cuestionamientos e intenciones México, D. F.: ERA.

Revueltas, J. (1981). Esto también era el mundo. En Las Cenizas. Obras Completas (Vol. 11). México, D. F.: ERA.

Revueltas, J. (1985). Hegel y yo. En A. Revueltas y P. Cheron (Eds.), José Revueltas. El apando y otros relatos. Madrid: Alianza.

Revueltas, J. (1986). Dialéctica de la conciencia (Vol. XX). México, D. F.: ERA.

Revueltas, J. (1989). El luto humano. México, D. F.: ERA.

Revueltas, J. (1991). Los días terrenales. Madrid: Colección Archivos ALLCA 1991. Print.

Revueltas, J. (1998). Ezequiel o la matanza de los inocentes En A. Revueltas y P. Cheron (Eds.), José Revueltas y el 68. México, D. F.: Universidad Nacional Autónoma de México, ERA.

Revueltas, J. (2001). Los errores. México, D. F.: ERA.
Revueltas, J. (2001). Los muros de agua. México, D. F.: ERA.

Revueltas, J. (2014). El reojo del yo. En Obra reunida. Relatos completos (Vol. 3). México, D. F.: ERA.

Romero, F. (1993). Sobre la filosofía en Iberoamérica. En ¿Qué es eso de filosofía latinoamericana? Bogotá: El Búho.

Salazar Ramos, R. (1983). Filosofía contemporánea: esbozos y textos. Bogotá: Universidad santo Tomás.

Salazar Ramos, R. (1988). Acerca de la filosofía latinoamericana en la última década en Colombia. En Tendencias actuales de la filosofía en Colombia. IV Congreso Internacional de Filosofía Latinoamericana. Bogotá: Universidad Santo Tomás

Salazar Ramos, R. (1993). Los Grandes meta-relatos en la interpretación de la historia latinoamericana. En Filosofía de la historia. VII Congreso Internacional de Filosofía Latinoamericana (Vol. II). Bogotá: Universidad Santo Tomás.

Salazar Ramos, R. (1993). Posmodernidad y verdad. Algunos metarrelatos en la constitución del saber. Bogotá: Universidad Santo Tomás.

Sánchez Lopera, A. (2009). El estallido de la verdad en América Latina. Nómadas, 31, 49-61.

Sánchez Lopera, A. (2012). Por una ética del desorden en América Latina. Nómadas, 37, 105-19.

Sánchez Prado, I. (2007). Bienaventurados los marginados porque ellos recibirán la redención: José Revueltas y el vaciamiento literario del marxismo. En F. Ramírez y M. Oyata (Eds.), El terreno de los días. Homenaje a José Revueltas. Puebla: 
Benemérita Universidad Autónoma de Puebla.

Sierra Mejía, R. (1996). La época de la crisis. Conversaciones con Danilo Cruz Vélez. Cali: Editorial Universidad del Valle.
Zea, L. (1969). La filosofía en América como filosofía sin más. México, D. F.: Siglo XXI.

Zea, L. (1991). Revueltas, el endemoniado. En E. Escalante (Ed.), Los días terrenales. Madrid: Colección Archivos ALLCA. 